\title{
Production and partial characterization of alkaline polygalacturonase secreted by thermophilic Bacillus sp. SMIA-2 under submerged culture using pectin and corn steep liquor
}

\author{
Produção e parcial caracterização de poligalacturonase secretada pelo termofílico \\ Bacillus sp. smia-2 em culturas submersas usando pectina e água de maceração de milho \\ Marcela Vicente Vieira de ANDRADE ${ }^{1}$, Andréia Boechat DELATORRE ${ }^{1}$, \\ Silvania Alves LADEIRA ${ }^{1}$, Meire Lelis Leal MARTINS ${ }^{1 *}$
}

\begin{abstract}
Polygalacturonase production by the thermophilic Bacillus sp. SMIA-2 cultivated in liquid cultures containing $0.5 \%$ (w/v) apple pectin and supplemented with $0.3 \%$ (w/v) corn steep liquor, reached its maximum after 36 hours with levels of 39 U.mL $\mathrm{mL}^{-1}$. The increase in apple pectin and corn steep liquor concentrations in the medium from 0.5 and $0.3 \%$, respectively, to $0.65 \%$, markedly affected the production of polygalacturonase, whose activity increased four times, reaching a maximum of $150.3 \mathrm{U} \cdot \mathrm{mL}^{-1}$. Studies on polygalacturonase characterization revealed that the optimum temperature of this enzyme was between $60-70{ }^{\circ} \mathrm{C}$. Thermostability profile indicated that the enzyme retained about 82 and $63 \%$ of its activity at 60 and $70{ }^{\circ} \mathrm{C}$, respectively, after 2 hours of incubation. The optimum pH of the enzyme was found to be 10.0. After incubation of crude enzyme solution at room temperature for 2 hours at $\mathrm{pH} 8.0$, a decrease of about $29 \%$ on its original activity was observed. At pH 10.0, the decrease was $25 \%$.

Keywords: polygalacturonase; corn steep liquor; Bacillus sp.; thermophilic bacterium.
\end{abstract}

\section{Resumo}

A produção de poligalacturonase pelo termofílico Bacillus sp. SMIA-2 cultivado em culturas líquidas contendo 0,5\% (p/v) de pectina de maçã e suplementado com $0,3 \%(\mathrm{p} / \mathrm{v})$ de água de maceração de milho foi máxima em 36 horas com níveis de 39 U.mL $\mathrm{m}^{-1}$. O aumento da concentração da pectina de maçã e da água de maceração de milho no meio de cultura de 0,5 e $0,3 \%$, respectivamente, para $0,65 \%$, afetou de maneira marcante a produção da poligalacturonase, cuja atividade aumentou cerca de quatro vezes, atingindo o valor máximo de 150,3 U.mL ${ }^{-1}$. Estudos sobre a caracterização da poligalacturonase revelaram que a temperatura para atividade ótima desta enzima foi entre $60-70{ }^{\circ} \mathrm{C}$. Em relação à termoestabilidade da enzima, a poligalacturonase manteve sua atividade em torno de 82 e $63 \%$ a 60 e $70{ }^{\circ} \mathrm{C}$, respectivamente, após 2 horas de incubação. O pH para atividade ótima da enzima foi 10,0. Após a incubação da solução enzimática bruta a $\mathrm{pH} 8,0$ por 2 horas à temperatura ambiente, foi observado um decréscimo em torno de $29 \%$ de sua atividade original. À pH 10,0 o decréscimo na atividade foi de $25 \%$.

Palavras-chaves: poligalacturonase; água de maceração de milho; Bacillus sp.; bactéria termofílica.

\section{Introduction}

Pectinases is a generic name for a family of enzymes that attack and depolymerize pectin through hydrolysis and trans-elimination, as well as by de-esterification reactions that hydrolyze the ester bond between the carboxyl and methyl of pectin groups (UENOJO; PASTORE, 2007). These enzymes include polygalacturonase (EC 3.2.1.15), pectin esterase (EC 3.1.1.11), pectin lyase (EC 4.2.2.10) and pectate lyase (EC 4.2.2.2), classified on the basis of their mode of action (ALKORTA et al., 1998; HOONDAL et al., 2002; KAPOOR; KUHAD, 2002).

Among many different applications, especially in the food industry, these enzymes are widely used in the clarification of wines and fruit juices. Further applications include the maceration of vegetables to facilitate the extraction of oils and pigments (GUPTA et al., 2007).

Polygalacturonase (E.C. 3.2.1.15) from microbial source is the most important pectinase used in industries. Thermostable polygalacturonases are of great significance as fruit juices are pasteurized at $50-60{ }^{\circ} \mathrm{C}$ (EL-SHEEKH et al., 2008). High temperatures not only reduce microbial contamination but also increase the solubility of pectin and decrease the viscosity of the liquid (MARTIN et al., 2007). Although a large number of organisms producing pectinases have been reported, the selection of potential isolates remains a tedious task, especially when physiologically potential strains are to be obtained in order to achieve maximum yield (SHARMA; SATYANARAYANA, 2006).

Recebido para publicação em 17/4/2009

Aceito para publicação em 25/9/2009 (004171)

Laboratório de Tecnologia de Alimentos, Centro de Ciências e Tecnologias Agropecuárias, Universidade Estadual do Norte Fluminense Darcy Ribeiro - UENF,

Av. Alberto Lamego, 2000, CEP 28015-620, Campos dos Goytacazes - RJ, Brasil, E-mail: meire@uenf.br

${ }^{*}$ A quem a correspondência deve ser enviada 
Bacteria belonging to Bacillus sp. are by far the most important source of several commercial microbial enzymes (ASGHER et al., 2007). They can be cultivated under extreme temperature and $\mathrm{pH}$ conditions, giving rise to products that are, in turn, stable in a wide range of harsh environments (WANG et al., 2007). Most Bacillus spp. have a wide range of hydrolytic enzyme systems and are often capable of utilizing the organic matter consisting of complex mixtures typical of most wastes; moreover, with the exception of the Bacillus cereus group (which includes Bacillus anthracis), they are harmless saprophytes that produce no toxins and are included in the group of organisms generally recognized as safe (GRAS) (MAHMOOD; GREENMAN; SCRAGG, 1998).

In the present paper, we report increased production of alkaline polygalacturonase from Bacillus sp. SMIA-2 grown in apple pectin and corn steep liquor. Furthermore, the enzyme respective stability and activity at different $\mathrm{pH}$ values and temperatures are presented as well.

\section{Materials and methods}

\subsection{Microorganism and culture conditions}

The bacterial strain used in this study was a thermophilic Bacillus sp. strain SMIA-2, previously isolated from a soil sample collected in Campos dos Goytacazes, Rio de Janeiro, Brazil (NUNES; MARTINS, 2001).

The culture medium used in this work for polygalacturonase production contained (g. $\mathrm{L}^{-1}$ of distilled water): apple pectin 5.0; corn steep liquor $3.0 ; \mathrm{KCl} 0.3 ; \mathrm{MgSO}_{4} 0.5 ; \mathrm{K}_{2} \mathrm{HPO}_{4}$ 0.87; $\mathrm{CaCl}_{2} 0.29 ; \mathrm{ZnO}-2.03 \times 10^{-3} ; \mathrm{FeCl}_{3} .6 \mathrm{H}_{2} \mathrm{O}-2.7 \times 10^{-2}$; $\mathrm{MnCl}_{2} .4 \mathrm{H}_{2} \mathrm{O}-1.0 \times 10^{-2} ; \mathrm{CuCl}_{2} .2 \mathrm{H}_{2} \mathrm{O}-8.5 \times 10^{-5}$; $\mathrm{CoCl}_{2} .6 \mathrm{H}_{2} \mathrm{O}-2.4 \times 10^{-3} ; \mathrm{NiCl}_{3} .6 \mathrm{H}_{2} \mathrm{O}-2.5 \times 10^{-4}$ and $\mathrm{H}_{3} \mathrm{BO}_{3}-3.0 \times 10^{-4}$. The $\mathrm{pH}$ was adjusted to 7.5 with $\mathrm{NaOH}$ and this medium was sterilized by autoclaving at $121{ }^{\circ} \mathrm{C}$ for 15 minutes. Pectin was sterilized separately and aseptically added to the flasks containing the liquid medium, after cooling. The above medium (50 in $250 \mathrm{~mL}$ Erlenmeyer flasks) was inoculated with $1 \mathrm{~mL}$ of an overnight culture and incubated at $50{ }^{\circ} \mathrm{C}$ in an orbital shaker (Thermo Forma, Ohio, USA) operated at $150 \mathrm{rpm}$. Triplicate flasks were withdrawn at regular intervals and analyzed for growth $(\mathrm{OD} 600 \mathrm{~nm})$ and $\mathrm{pH}$. The contents were then centrifuged at 15,500 $\mathrm{g}$ for 15 minutes at $4{ }^{\circ} \mathrm{C}$ and the cell free supernatant was used as crude enzyme preparation.

\subsection{Enzyme assay}

Polygalacturonase activity was measured by quantifying reducing groups expressed as galacturonic acid units, which had been liberated during the incubation of $800 \mu \mathrm{L}$ of $0.5 \%$ $(\mathrm{w} / \mathrm{v})$ citrus pectin, prepared in $0.2 \mathrm{M}$ borax $-\mathrm{NaOH}$ buffer, $\mathrm{pH} 10$ with $200 \mu \mathrm{L}$ of the enzyme at $70{ }^{\circ} \mathrm{C}$, for 10 minutes, by DNSA method (MILLER, 1959). One unit of the enzyme activity $(\mathrm{U})$ was defined as the amount of enzyme required to release $1 \mu \mathrm{mol}$ of galacturonic acid from the citrus pectin at $70{ }^{\circ} \mathrm{C}$ in 1 minute.

\subsection{Effect of pH on activity and stability of the enzyme}

The optimum $\mathrm{pH}$ for polygalacturonase activity was determined with citrus pectin $0.5 \%(\mathrm{w} / \mathrm{v})$ as substrate, dissolved in different buffers (citrate phosphate, $\mathrm{pH}$ 6.0-6.5, sodium phosphate, $\mathrm{pH} 7.0-7.5$, Tris- $\mathrm{HCl}, \mathrm{pH} 8.0-8.5$ and glycine $\mathrm{NaOH}$, $\mathrm{pH} 9.0-12.0)$.The stability of the enzyme at different $\mathrm{pH}$ values was also studied by incubating the enzyme at various $\mathrm{pH}$ values ranging from 6.0 to 12.0 for 2 hours, and then estimating the residual activity. The used buffers were the same described above.

\subsection{Effect temperature on activity and stability of the enzyme}

The effect of temperature on the enzyme activity was determined by performing the previously described standard assay procedure for 10 minutes at $\mathrm{pH} 8.5$ within a temperature range of $40-100^{\circ} \mathrm{C}$. Thermostability was determined through incubation of the enzyme at temperatures ranging from $40-100{ }^{\circ} \mathrm{C}$ for 2 hours in a constant-temperature water bath. After treatment, the residual enzyme activity was assayed.

\section{Results and discussion}

\subsection{Enzymatic production}

Bacillus sp. strain SMIA-2, when cultivated in a liquid medium containing apple pectin $(0.5 \%)$ as a carbon source and supplemented with corn steep liquor $(0.3 \%)$, produced polygalacturonase (Figure 1). It was observed that maximum polygalacturonase production $\left(39 \mathrm{U} \cdot \mathrm{mL}^{-1}\right)$ occurred after the cell population reached the peak, suggesting that this organism may be unusually sensitive to metabolic repression. Effective induction of polygalacturonase may not occur until the stationary phase is reached and the readily available carbon source is depleted. In Bacillus sp. MG-cp-2 growing in minimal medium supplemented with $1 \%(\mathrm{w} / \mathrm{v})$ citrus pectin as the sole carbon source, it was observed that the maximum polygalacturonase activity $\left(47 \mathrm{U} \cdot \mathrm{mL}^{-1}\right)$ was obtained when cell population reached the peak. However, the polygalacturonase

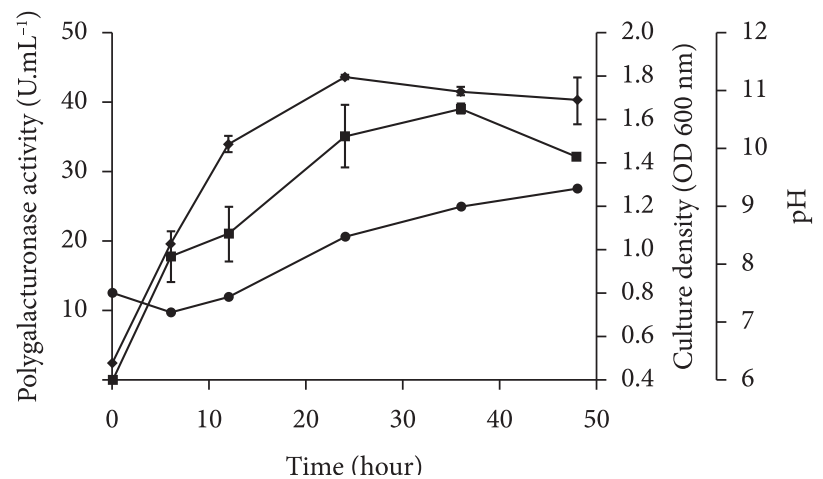

Figure 1. Time course of polygalacturonase production by Bacillus sp. strain SMIA-2 grown at $50{ }^{\circ} \mathrm{C}$ on $0.5 \% \mathrm{w} / \mathrm{v}$ apple pectin and $0.3 \% \mathrm{w} / \mathrm{v}$ corn steep liquor in shake flasks. Bars indicate \pm 1 standard deviation. Absence of bars indicates that the errors were smaller than the symbols. Enzymatic activity (ם); Optical density $(\bullet)$ and $\mathrm{pH}(\bullet)$. 
yield in enriched medium containing $0.5 \%$ yeast extract was $98{\mathrm{U} . \mathrm{mL}^{-1}}^{-1}$ after 20 hours (KAPOOR et al., 2001). In fact, it has been shown that enhanced enzyme production is achieved for other strains including Bacillus species when increasing the nitrogen availability in the medium, generally by means of yeast extract and/or peptone addition (SAXENA et al., 2007; ASHIS; MUKHERJEE; SUDHIR, 2008).

In our experiment, supplementation with corn steep liquor provided an additional nitrogen source, by providing peptides and amino acids made readily available for cell metabolism, and showed an increase in polygalacturonase production. Therefore, the co-utilization of pectin and corn steep liquor is an attractive choice for polygalacturonase production by Bacillus sp. SMIA-2, since both are a good source of nutrients and important metal ions (DIAS et al., 2008; RIVAS; MOLDES; DOMINGUEZ, 2004), and are also inexpensive. Thus, the simple expedient of supplementing the medium with corn steep liquor would result in a reduction in the costs of polygalacturonase production by Bacillus sp. SMIA-2.

The medium $\mathrm{pH}$ declined from 7.5 to 7.2 within 6 hours and thereafter, started to rise again till it reached 9.3. This may indicate that some organic nitrogen was being consumed.

Increasing apple pectin and corn steep liquor concentrations in the medium from 0.5 and $0.3 \%$, respectively, to $0.65 \%$, did not affect the growth of the organism, but noticeably affected the activity of polygalacturonase. Under these conditions, the polygalacturonase activity increased four times, reaching a maximum of $150.3 \mathrm{U} \cdot \mathrm{mL}^{-1}$ (Figure 2).

Andrade (2008) studied the polygalacturonase production by Bacillus sp. SMIA-2 using the response surface methodology. According to this author, the corn steep liquor showed a positive effect, resulting in a linear increase on the polygalacturonase production when its content was increased. On the other hand, the enzyme production was distinctly reduced by increasing the pectin concentration - pointing out the importance of working at low levels of the inductor. The maximum polygalacturonase production was achieved by employing $0.3 \%$ pectin and $1.0 \%$ corn steep liquor.

An increase in the pectin concentration resulted in an increase in polygalacturonase production by Penicillium SPC-F 20. The maximum level so attained was at 1\% (MATHEW; ELDO; MOLLY, 2008).

In Streptomyces sp. RCK-SC, it was found that, among the various organic and inorganic nitrogen sources added to medium containing pectin $(0.25 \%)$ and glucose $(0.25 \%)$ as carbon sources, urea $(0.25 \% \mathrm{w} / \mathrm{v})$ favored maximum pectinase production, while corn-steep liquor did not support high pectinase production (KUHAD; KAPOOR; RUSTAGI, 2004).

\subsection{Effect of temperature and $p H$ on enzyme activity and stability}

The polygalacturonase from Bacillus sp. SMIA-2 was found to be maximally active between 60 and $70^{\circ} \mathrm{C}$. Temperature kinetics of polygalacturonase suggested that the enzyme activity rose steadily up to $70^{\circ} \mathrm{C}$ and thereafter, it sharply declined (Figure 3).
Temperature optima of $60^{\circ} \mathrm{C}$ were reported for pectinases from Bacillus sp. MG-cp-2 (KAPOOR et al., 2001) and Streptomyces sp. QG-11-3 (BEG et al., 2001), whereas lower temperature optima of 45 and $50{ }^{\circ} \mathrm{C}$ were reported for pectinases from Sclerotinia sclerotiorum (RIOU; FREYSSINET; FEVRE, 1992) and Saccharomyces cerevisiae (BLANCO et al., 1998), respectively.

Thermostable enzymes such as polygalacturonases are advantageous for some applications, because higher processing temperatures can be employed with the advantage of faster reaction rates, increase in the solubility of nongaseous reactants and products, and reduced incidence of microbial contamination from mesophilic organisms (WANG et al., 2007).

Besides temperature optima, the thermostability of the polygalacturonase was examined by measuring the remaining activities at $60{ }^{\circ} \mathrm{C}$, after incubation of the enzymes without substrate at various temperatures between 40 and $100{ }^{\circ} \mathrm{C}$ for 2 hours (Figure 3 ). The enzyme was thermostable and retained about $82 \%$ of its activity at $70{ }^{\circ} \mathrm{C}$ after 2 hours of incubation.

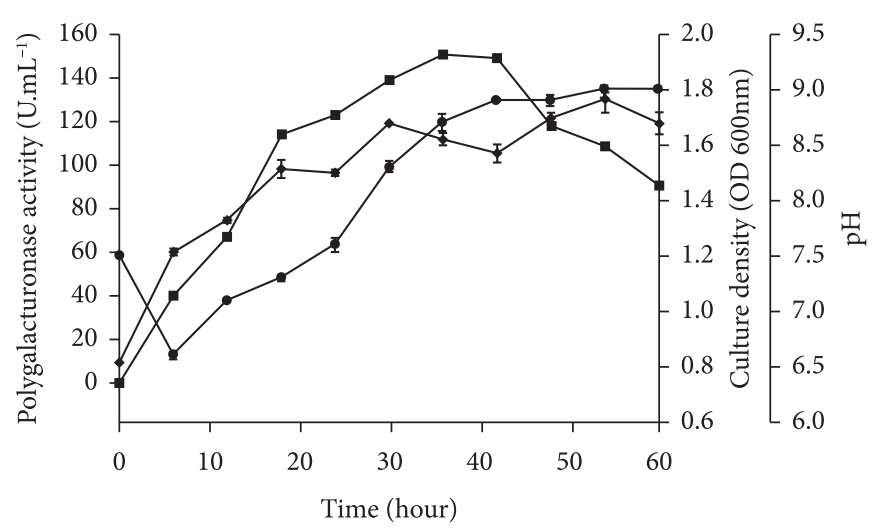

Figure 2. Time course of polygalacturonase production by Bacillus sp. strain SMIA-2 grown at $50^{\circ} \mathrm{C}$ on $0.65 \% \mathrm{w} / \mathrm{v}$ apple pectin and $0.65 \% \mathrm{w} / \mathrm{v}$ corn steep liquor in shake flasks. Bars indicate \pm 1 standard deviation. Absence of bars indicates that the errors were smaller the than symbols. Enzymatic activity $(\boldsymbol{\bullet})$; Optical density $(\diamond)$ and $\mathrm{pH}(\bullet)$.

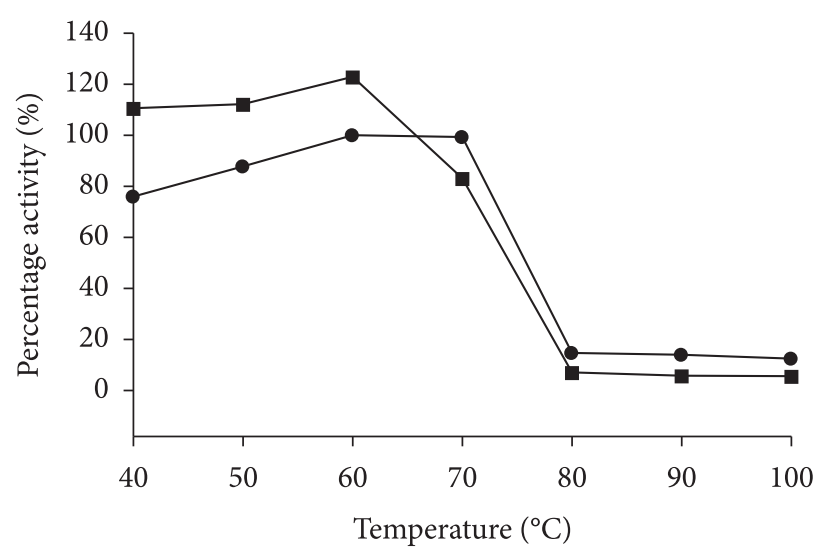

Figure 3. Optimum temperature (•) and stability (ם) of polygalacturonase produced by Bacillus sp. grown at $50{ }^{\circ} \mathrm{C}$ at $0.65 \%$ $\mathrm{w} / \mathrm{v}$ apple pectin and $0.65 \% \mathrm{w} / \mathrm{v}$ corn steep liquor in shake flasks for 36 hours. Relative activity is expressed as a percentage of the maximum $\left(100 \%\right.$ of enzyme activity $\left.=154.4 \mathrm{U} \cdot \mathrm{mL}^{-1}\right)$. 


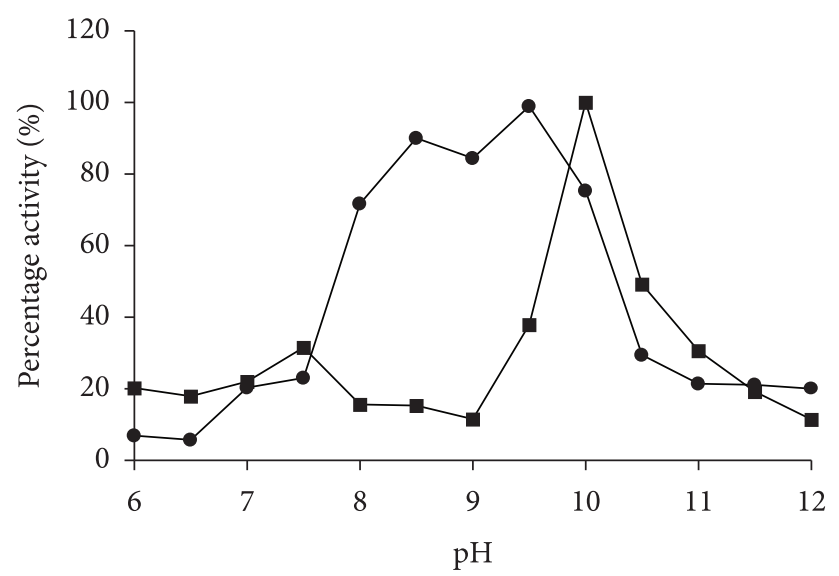

Figure 4. Optimum $\mathrm{pH}(\boldsymbol{\square})$ and stability ( $\bullet$ ) of polygalacturonase produced by Bacillus sp. grown at $50{ }^{\circ} \mathrm{C}$ at $0.65 \% \mathrm{w} / \mathrm{v}$ apple pectin and $0.65 \% \mathrm{w} / \mathrm{v}$ corn steep liquor in shake flasks for 36 hours. Relative activity is expressed as a percentage of the maximum (100\% of enzyme activity $=132 \mathrm{U} \cdot \mathrm{mL}^{-1}$ ).

The thermostability of the enzyme investigated competed favorably with those reported for the genus Bacillus (KUHAD; KAPOOR; RUSTAGI, 2004).

The polygalacturonase exhibited optimum activity at $\mathrm{pH} 10$ (Figure 4). The enzyme was stable over the $\mathrm{pH}$ range 8 -10. More than 71 and $75 \%$ activities were retained at $\mathrm{pH} 8.0$ and 10, respectively.

Pectinases with alkaline $\mathrm{pH}$ optima were reported from Bacillus sp. NT-2, NT-6, NT-33 and NT-82 (CAO; ZHENG; CHEN, 1992). Bacillus sp. MG-cp-2 (KAPOOR et al., 2001), and Bacillus sp. strain KSM-P15 (KOBAYASHI et al., 2003). Thus, the polygalacturonase of Bacillus sp. strain SMIA-2 seems to be active in a very broad $\mathrm{pH}$ range and it could find several industrial uses.

\section{Conclusion}

Bacillus sp. strain SMIA-2 produces polygalacturonase when growing at $50{ }^{\circ} \mathrm{C}$ in a culture medium containing apple pectin $(0.65 \%, \mathrm{w} / \mathrm{v})$ and corn steep liquor $(0.65 \%, \mathrm{w} / \mathrm{v})$.

The enzyme exhibits optimum activity at $\mathrm{pH} 10$ and temperature between 60 and $70{ }^{\circ} \mathrm{C}$. It retains about $82 \%$ of its activity at $70{ }^{\circ} \mathrm{C}$ after 2 hours of incubation and it is stable over the $\mathrm{pH}$ range $8-10$. Therefore, the enzyme could find several industrial uses.

\section{Acknowledgements}

The authors are highly grateful to 'CNPq' (Conselho Nacional de Desenvolvimento Científico e Tecnológico) for the financial support.

\section{References}

ALKORTA, I. et al. Industrial applications of pectic enzymes: A review. Process Biochemistry, v. 33, n.1, p. 21-28, 1998.
ANDRADE, M. V. V. Produção e caracterização de poligalacturonase pelo termofílico Bacillus sp. SMIA-2. 2008. 65 f. Dissertação (Mestrado em Produção Vegetal)-Departamento de Tecnologia dos Alimentos, Universidade Estadual do Norte Fluminense, Campos dos Goytacazes, 2008.

ASGHER, M. et al. A thermostable $\alpha$-amylase from a moderately thermophilic Bacillus subtilis strain for starch processing. Journal of Food Engineering, v. 79, n. 5, p. 950-955, 2007.

ASHIS, K.; MUKHERJEE, H. A.; SUDHIR, K. R. Production of alkaline protease by a thermophilic Bacillus subtilis under solid-state fermentation (SSF) condition using Imperata cylindrical grass and potato peel as low-cost medium: characterization and application of enzyme in detergent formulation. Biochemical Engineering Journal, v. 39, n.3, p. 353-361, 2008.

BEG, Q.K. et al. Bleach-boosting of eucalyptus kraft pulp using combination of xylanase and pectinase from Streptomyces sp. QG11-3. Resource Bull Panjab University, v. 57, n.1, p.71-78, 2001.

BLANCO, P. et al. Cloning, molecular characterization, and expression of an endopolygalacturonase- encoding gene from Saccharomyces cerevisiae IM1-8b. FEMS Microbiology Letters, v. 164, n. 3, p. 249255, 1998.

CAO, J.; ZHENG, L.; CHEN, S. Screening of pectinase producer from alkalophilic bacteria and study on its potential application in degumming of ramie. Enzyme and Microbial Technology, v. 14, n. 9, p.1013-1016, 1992.

DIAS, D. R. et al. Alkaline protease from Bacillus sp. isolated from coffee bean grown on cheese whey. World Journal Microbiology Biotechnology, v. 24, n. 11, p. 2027-2034, 2008.

EL-SHEEKH, M. M. et al. Effective techonological pectinases by Aspergillus carneus NRC1 utilizing the Egyptian orange juice industry scraps. International Biodeterioration and Biodegradation v. 38, n. 1, p. 1-7, 2008.

GUPTA, S. et al. Production and recovery of an alkaline exopolygalacturonase from Bacillus subtilis RCK under solid-state fermentation using statistical approach. Bioresource Technology, v. 99, n. 7, p. 937-945, 2007.

HOONDAL, G. S. et al. Microbial alkaline pectinases and their industrial applications: a review. Applied Microbiology and Biotechnology, v. 59, n. 3, p. 409-418, 2002.

KAPOOR, M. et al. Application of an alkaline and thermostable polygalacturonase from Bacillus sp. MG-cp-2 in degumming of ramie (Boehmeria nivea) and sunn hemp (Crotalaria juncea) bast. bres. Process Biochemistry, v. 36, n. 6, p. 803-807, 2001.

KAPOOR, M; KUHAD, R. C. Improved polygalacturonase production from Bacillus sp. MG-cp-2 under submerged (SmF) and solid state (SSF) fermentation. Letters in Applied Microbiology, v. 34, n. 3, p. 317-322, 2002.

KOBAYASHI, T. et al. Bifunctional pectinolytic enzyme with separate pectate lyase and pectin methylesterase domains from an alkalophilic Bacillus. World Journal of Microbiology and Biotechnology, v. 19, n. 3, p. 269-277, 2003.

KUHAD, R. C.; KAPOOR, M.; RUSTAGI, R. Enhanced production of an alkaline pectinase from Streptomyces sp. RCK-SC by wholecell immobilization and solid-state cultivation. World Journal of Microbiology \& Biotechnology, v. 20, n.3, p. 257-263, 2004.

MAHMOOD, A.U; GREENMAN, J; SCRAGG, A.H. Orange and potato pell extracts: Analysis and use as Bacillus substrates for the production of extracellular enzymes in continuous culture. Enzyme Microbial Technology, v. 22, n. 1, p. 130-137, 1998. 
MARTIN, N. et al. Study of pectinase produced by thermophilic fungi Rhizomucor sp. N31 in FES. Journal of Biotechnology, v. 131, n. 2, p.158-163, 2007.

MATHEW, A.; ELDO, A. N.; MOLLY, A. G. Optimization of culture conditions for the production of thermostable polygalacturonase by Penicillium SPC-F 20; Journal of Industrial Microbiology and Biotechnology, v. 35, n. 9, p. 1001-1005, 2008.

MILLER, G. L. Use of dinitrosalicylic acid reagent for determination of reducing sugars. Analytical Chemistry, v. 3, n. 3, p. 426-428, 1959.

NUNES, A. S; MARTINS, M. L. L. Isolation, properties and kinetics of growth of a thermophilic. Bacillus. Brazilian Journal of Microbiology, v. 32, n. 2, p. 271-275, 2001.

RIVAS, B.; MOLDES, A. B.; DOMINGUEZ, J. C. Development of culture media containing spent yeast cells of Debaryomyces hansenii and corn steep liquor for lactic acid production with Lactobacillus rhamnosus. International Journal of Food Microbiology, v. 97, n. 1, p. 93-98, 2004.
RIOU,C.; FREYSSINET, G.; FEVRE, M. Purification and characterization of extracellular pectinolytic enzyme produced by Sclerotinia sclerotiorum. Applied and Environmental Microbiology, v. 58, n. 4, p. 578-583, 1992.

SAXENA, R. K. et al. A highly thermostable and alkaline amylase from Bacillus sp. PN5. Bioresource Technology, v. 98, n. 2, p. 260-265, 2007.

SHARMA, D. C.; SATYANARAYANA, T. A marked enhancement in the production of a highly alkaline and thermostable pectinase by Bacillus pumilus dcsr 1 in submerged fermentation by using statistical methods. Bioresource Technology, v. 97, n. 6, p. 727-733, 2006.

UENOJO, M; PASTORE, G. M. Pectinases: Aplicações industriais e perspectivas. Quimica Nova, v. 30, n. 3, p. 388-394, 2007.

WANG, Q. et al. Optimizing bioscouring condition of cotton knitted fabrics with an alkaline pectinase from Bacillus subtilis WSHB04-02 by using response surface methodology. Biochemical Engineering Journal, v. 34, n. 1, p. 107-113, 2007. 